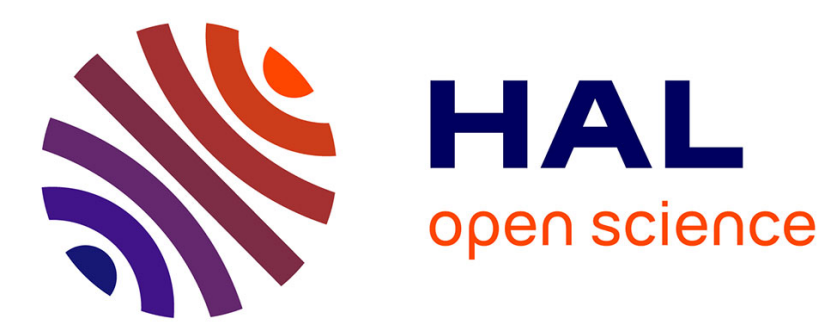

\title{
The Aristocracy and the Empire of Nicaea
}

Vincent Puech

\section{- To cite this version:}

Vincent Puech. The Aristocracy and the Empire of Nicaea. J. Herrin et G. Saint-Guillain. Identities and Allegiances in the Eastern Mediterranean after 1204, Ashgate, pp.69-80, 2011. hal-02568865

\section{HAL Id: hal-02568865 \\ https://hal.science/hal-02568865}

Submitted on 14 May 2020

HAL is a multi-disciplinary open access archive for the deposit and dissemination of scientific research documents, whether they are published or not. The documents may come from teaching and research institutions in France or abroad, or from public or private research centers.
L'archive ouverte pluridisciplinaire HAL, est destinée au dépôt et à la diffusion de documents scientifiques de niveau recherche, publiés ou non, émanant des établissements d'enseignement et de recherche français ou étrangers, des laboratoires publics ou privés. 


\title{
Chapter 4
}

\section{The Aristocracy and the Empire of Nicaea*}

\author{
Vincent Puech
}

The Prosopography of the Byzantine World project addresses the crucial problem of the unity of the Christian eastern Mediterranean in the thirteenth century. For Byzantium, this unity depended on two factors: recognition of the authority of both state and church, after the fall of the capital city to the Latins. When the patriarchate was reconstituted in Nicaea in 1208 , it set up the main religious identity factor in the Byzantine world. It was more difficult for the government of Nicaea to secure its imperial legitimacy. In this contribution I shall investigate how this regime in Nicaea succeeded or failed to establish its internal legitimacy, against the views and claims of areas outside the empire of Nicaea. My perspective will be based on a direct prosopographical approach, looking at aristocratic support for and opposition to the so-called emperors 'of Nicaea'. The Byzantine aristocracy was always led by two complementary principles: the possession of imperial titles and local power. It is crucial to grasp the relationship between these two principles in the thirteenth century, for it allows us to study the phenomena of unity and dissent that characterized the Byzantine world at that time. This in turn permits a test case, analysing the different aristocratic groups that supported the Laskaris dynasty and the Palaiologos family that eventually gained supreme power. The replacement of the former by the latter, which occurred during Nicaea's European expansion, suggests the possibility of multiple allegiances.

The retreat of Theodore Laskaris to Asia Minor in 1204 is difficult to explain with any precision, although we do possess some clues. The Laskaris clan may have had its distant origins in the military world of the East, as the etymology of the name suggests: laskar means 'warrior' in Persian. ${ }^{1}$ What is more, a seal that certainly belonged to the future Theodore I betrays the links of the family with Asia Minor. ${ }^{2}$ Its legend mentions a Theodore Komnenos Laskaris, sebastos and

* I am very grateful to Ruth Macrides and Judith Herrin for inviting me to the PBW colloquium, to Judith Herrin and Michael Angold for their advice, and to Tassos Papacostas for translating my paper.

1 Alexander P. Kazhdan and Anthony Cutler, 'Laskaris', in Alexander P. Kazhdan (ed.), The Oxford Dictionary of Byzantium, 3 vols (New York-Oxford, 1991), vol. 2, pp. $1180-81$.

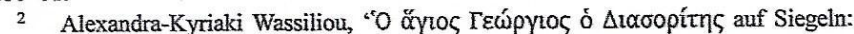
ein Beitrag zur Frühgeschichte der Laskariden', Byzantinische Zeitschrift, 90 (1997): pp. $416-26$. 
protobestiarites: the relationship with the Komnenoi and the high status of both dignity and office strongly suggest that the owner was the future emperor. The seal dates from before 1203, the year in which Theodore was made despotes by Alexios III Angelos, who also married him to his daughter Anna, thus placing him next in line to the throne. The seal bears on its reverse the image of St George Diasorites, a rarely used epithet. The main cult centre for St George Diasorites was a monastery at Pyrgion in the upper valley of the Kaystros (see Map). It is therefore very likely that Theodore Laskaris maintained some link with Asia Minor before 1203. In 1204 he was acknowledged as military leader (strategos) of north-western Asia Minor (Bithynia) by the local population, according to Niketas Choniates. ${ }^{3}$ During the same period, however, the city of Nicaea refused to recognize his power. ${ }^{4} \mathrm{He}$ was not proclaimed emperor until 1205 and not crowned until even later, in 1208, when a new patriarch was finally elected. ${ }^{5}$ It is therefore important to investigate how such an accession to power came about.

Theodore Laskaris enjoyed the support of certain members of the Kamateros and Autoreianos clans, two Constantinopolitan families of high-ranking officials. Nevertheless, in the beginning he faced the hostility of Patriarch John X Kamateros, who moved to Thrace, not to Asia Minor, and refused to join the Laskarids in Nicaea; he resigned from his position in 1206.6 At the same time Theodore Laskaris enjoyed the backing of the sebastos Basil Kamateros, brother-in-law of Alexios III Angelos and logothetes tou dromou under the same emperor. A letter of Michael Choniates to Basil shows the influence the latter exerted in the election of Patriarch Michael IV Autoreianos. ${ }^{7}$ The Autoreianoi and Kamateroi were related through links of kinship. According to the anonymous encomium of the future Patriarch Arsenios, the latter's father was Alexios Autoreianos, krites tou belou at Constantinople, while his mother was a certain Irene Kamaterissa. ${ }^{8}$ The two families were clearly allied and this alliance was put at the disposal of the Laskarids.

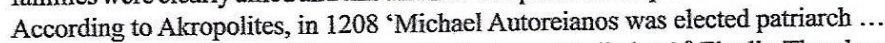
He crowned the despotes Theodore with the imperial diadem' ${ }^{\prime}$. Finally Theodore Laskaris was backed in his defence of Bithynia by his brother Constantine, who

3 Nicetae Choniatae Orationes et epistulae, ed. I.A. van Dieten, 2 vols (Berlin-New York, 1972), vol. 1, p. 134.

4 Georgii Acropolitae Opera, ed. A. Heisenberg, 2 vols (Leipzig, 1903), vol. 1, p. 10.

5 Michael Angold, A Byzantine Government in Exile: Government and Society under the Laskarids of Nicaea, 1204-1261 (Oxford, 1974), p. 13.

6 Jean-Claude Cheynet, Pouvoir et contestations à Byzance (963-1210) (Paris, 1990), pp. 135 and 470.

7 Michaelis Choniatae Epistulae, ed. F. Kolovou (Berlin, 2001), pp. 208-11.

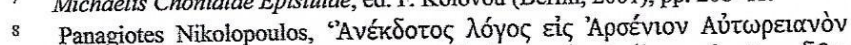

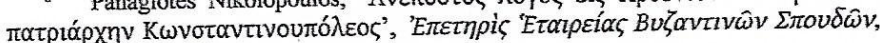
45 (1981-82): pp. 406-61.

9 George Alkropolites, The History, transl. R. Macrides (Oxford, 2007), p. 119. 
fought against the Latins at Atramyttion in 1205, and by the same or another of his brothers who fought against them at Lentiana in 1212/1213. ${ }^{10}$

As far as internal affairs are concerned, the main difficulty faced by Theodore Laskaris was the disloyalty of three of the magnates of the theme of Thrakesion In this case the new emperor received help from another of his brothers, the sebastokrator George, which is attested in a record probably relating to 1212 , but preserved in a later source. ${ }^{11}$ Between the summer of 1205 and the spring of 1206, Theodore Mankaphas was overcome by the Laskarid troops in the region of Philadelphia. ${ }^{12}$ According to Niketas Choniates, Theodore Laskaris then secured the allegiance of Smyma and Ephesos. The elimination of Mankaphas allowed him to reach the upper valley of the Meander, where the kaisar Manuel Maurozomes was established. Maurozomes secured Turkish troops from his father-in-law, the Seljuk sultan, but was also subdued in late 1205 by Laskaris, who then negotiated a compromise: Maurozomes was to maintain his rule over Chonai and Laodikeia. At the end of 1205 Sabbas Asidenos, ruler in the region of Priene, was defeated in the lower Meander valley. ${ }^{13}$ Among the three vanquished dynasts he is the one who best preserved his power, for he is attested in 1214 as sebastokrator, allied to the imperial family. ${ }^{14}$ In his struggle against the three rebels Theodore Laskaris received considerable support from the aristocracy of the lower Meander valley. ${ }^{15}$ This group of dignitaries is well documented in the cartulary of Patmos, its most representative example being the protobestiarios George Eunouchos, a great landowner recorded between 1207 and $1213 .^{16}$

The question of who would succeed Theodore I Laskaris was marked by a sequence of missed opportunities. His natural heir would have been his son Nicholas, who died young. ${ }^{17}$ The emperor was no luckier with the husband of his eldest daughter Irene, the despotes Palaiologos, who also died before him. ${ }^{18}$ Irene's second marriage to John Batatzes created a third option for the succession. Theodore I certainly did not envisage this course, for he avoided promoting

10 Georgii Acropolitae Opera, ed. Heisenberg, vol. 1, p. 29

11 Franz Miklosich and Joseph Müller (eds), Acta et diplomata Graeca medii aevi sacra et profana, 6 vols (Vienna, 1860-90), vol. 4, pp. 35-8.

12 Jean-Claude Cheynet, 'Philadelphie, un quart de siècle de dissidence, 1182-1206', in Philadelphie et autres études (Paris, 1984), pp. 39-54.

13 Georgii Acropolitae Opera, ed. Heisenberg, vol. 1, p. 12.

14 Jean Darrouzès and Nigel Wilson, 'Restes du cartulaire de Hiéra-Xèrochoraphion', Revue des études byzantines, 26 (1968): pp. 5-47.

15 Miklosich and Müller (eds), Acta et diplomata, vol. 4, pp. 35-8.

16 Ibid., vol. 6, pp. 151-65.

17 Vitalien Laurent, Les regestes des actes du patriarcat de Constantinople. I. Les actes des patriarches, vol. 4, Les regestes de 1208 à 1309 (Paris, 1971), pp. 6-8.

is Jean-François Vannier, 'Les premiers Paléologues. Étude généalogique et prosopographique', in Jean-Claude Cheynet and Jean-François Vannier, Etudes prosopographiques (Paris, 1986), pp. 123-88. 
Batatzes to the dignity of despotes; instead, he kept him at the much lower rank of protobestiarites. Nevertheless, the conclusion of this marriage alliance and John Batatzes' accession to power testify to his influence in the new empire of Nicaea, which was very likely connected with his status within the theme of Thrakesion. It is almost certain that John was the son of Basil Batatzes, domestikos of the East and doux of Thrakesion under Isaac II Angelos. ${ }^{19}$ Basil had succeeded in expelling Mankaphas from Philadelphia, the first time by bribing most of his supporters. ${ }^{20}$ An earlier John Batatzes, megas domestikos and dotx of Thrakesion under Manuel I Komnenos, had defended the area against the Turks and distributed his booty among the inhabitants of Philadelphia. ${ }^{21}$ In short, the Batatzes clan offered the Nicaean emperors a crucial means of controlling Philadelphia, capital of the theme of Thrakesion.

Not surprisingly, the accession to power of John III Batatzes provoked the hostility of the Laskaris clan and of its closest allies. The two brothers of Theodore I, the sebastokratores Alexios and Isaac Laskaris, went over to Latin territory, but were defeated (together with a Latin contingent) by John III at Poimanenon and were subsequently blinded. ${ }^{22}$ The revolt was prolonged into 1225 by a conspiracy of Laskarid supporters. ${ }^{23}$ This campaign was centred on the town of Achyraous in Mysia, near the Nicaean cradle of the dynasty. The rebellion was led by the brothers Andronikos and Isaac Nestongos, cousins of the emperor. They were joined by one of the Tarchaneiotes, a family probably already linked to theirs. ${ }^{24}$ Another conspirator was Synadenos, whose family had been in the service of David Komnenos in Paphlagonia in 1204.25 Although the Synadenos of that earlier rebellion had been defeated by Theodore I, this incident reveals the establishment of the clan in northern Asia Minor. Another conspirator, Makrenos, was accused of planning to murder John III; together with Isaac Nestongos he was blinded and had his hand amputated.

19 Demetrios Polemis, The Doukai: A Contribution to Byzantine Prosopography (London, 1968), no. 72. Alluding to a projected marriage between Michael Palaiologos and a daughter of Theodore II who was the latter's second cousin, Akropolites seems to imply that John III himself married the daughter of his own second cousin (Georgii Acropolitae Opera, ed. Heisenberg, vol. 1, p. 100). Indeed, John Batatzes' wife, Irene Laskarina, was the granddaughter of Alexios III, who was also the cousin of Basil Batatzes' wife: Nicetae Choniatae Historia, ed. I.A. van Dieten, 2 vols (Berlin-New York, 1975), vol. I, pp. 400 and 435 .

$20 \quad$ Ibid., vol. 1, p. 400.

21 Cheynet, Pouvoir et contestations, p. 113.

22 Georgii Acropolitae Opera, ed. Heisenberg, vol. 1, pp. 31-5.

23 Ibid., vol. 1, pp. 36-7.

24 August Heisenberg, Quellen und Studien zur spätbyzantinischen Geschichte (London, 1973), p. 11. A daughter from a first marriage of the megas domestikos Nikephoros Tarchaneiotes was married to a Nestongos.

Is Nicetae Choniatae Historia, ed. Van Dieten, vol. 1, p. 626. 
The dependence of the Laskarids on northern Asia Minor is also obvious in the idcological and political role of the porphyrogennetos Theodore, the future emperor Theodore II, son of John III. He is the author of an encomium of Nicaea, written towards the very end of his father's reign, probably between early 1252 and 1254 and certainly before November $1254 .{ }^{26}$ It is well known that from the beginning of the reign of John III the permanent capital of the empire was at Nymphaion near Smyrna; Nicaea was only the seat of the patriarchate. Nevertheless, the Bithynian capital is presented by Theodore as the seat of imperial power. This ideological choice fits perfectly into the political role assumed by Theodore towards the end of his father's reign. In 1241 and then again in 1246, during the military campaigns of John III in the Balkans, the porphyrogennetos was entrusted with the administration of the East. ${ }^{27}$ The episode of 1241 is relatively well documented by Akropolites: at that time Theodore was staying in the region of Pegai and was assisted by the monk John Mouzalon, a former mystikos. Interestingly, if we are to trust Pachymeres, the Mouzalon clan hailed from Atramyttion; ${ }^{28}$ this local origin was therefore helpful for Theodore. In addition, a Mouzalon was governor of the city of Nicaea in around 1227 ; it is possible, although not certain, that he is identical with John Mouzalon. ${ }^{29}$

Prosopography allows a reassessment of the importance of the Mouzalon clan: its members were not the newcomers described in the anti-Laskarid sources. It is true that until the reign of Theodore II the Mouzalones were not related to the emperor; this explains why Pachymeres denies them 'good birth' (eugeneia). But one has to remember that in the eleventh century George Mouzalon was patrikios and symponos. ${ }^{30}$ Under Manuel I Komnenos Nicholas Mouzalon ascended the patriarchal throne. ${ }^{31}$ Thus the family belonged to a layer of the aristocracy just below the nexus of clans with kinship links to the emperor. To return to the entourage of the porphyrogennetos Theodore, we know that the brothers George and Andronikos Mouzalon were appointed attendants (paidopouloi) to the heir of the throne. At the end of the reign of John III they received titles: George was

26 Laurence Delobette, 'Oublier Constantinople? L'Éloge de Nicée par Théodore II Lascaris', in Les villes capitales au Moyen Age (Paris, 2006), pp. 349-72.

27 Georgii Acropolitae Opera, ed. Heisenberg, vol. 1, pp. 67 and 71. For the date of 1241 see George Akropolites, The History, transl. Macrides, p. 216.

28 Georges Pachymérès, Relations historiques, ed. A. Failler and trans1. V. Laurent, 5 vols (Paris, 1984-2000), vol. 1, p. 41.

29 This identification is suggested by Joseph Munitiz: Nicephori Blemmydae Autobiographia sive curriculum vitae, ed. J. Munitiz (Tumhout-Leuven, 1984), pp. 5960.

30 Unpublished seals of Dumbarton Oaks: DO 55. 1. 3197 and 3198. I thank JeanClaude Cheynet for providing me with these documents.

31 Venance Grumel and Jean Darrouzès, Les regestes des actes du patriarcat de Constantinople. I. Les actes des patriarches, vols 2-3, Les regestes de 715 à 1206 (Paris, 1989), pp. 486-90. 
made megas domestikos and Andronikos protobestiarites. ${ }^{32}$ Thanks to the study of his abundant correspondence the description of Theodore's entourage may be extended from letters dating both before and after his accession to power. His secretary was Konstas Hagiotheodorites, who was married to a sister of George Mouzalon. ${ }^{33}$ A Kammytzes, a member of a family owning estates in the Meander valley, ${ }^{34}$ was a friend of both Theodore and George Mouzalon. ${ }^{35}$ Finally the porphyrogennetos corresponded with Andronikos, metropolitan of Sardis and a native of Paphlagonia, ${ }^{36}$ and with Phokas, metropolitan of Philadelphia. ${ }^{37}$

Across the Bosporos the capitulation of the European provinces to John III Batatzes was secured to a large extent thanks to the local aristocracy that had exerted power there before 1204 . The first case concerns Thrace and more precisely the town of Tzouroulos, captured by John III in 1235-36, then recaptured by the Latins in 1239-40. During the two campaigns the Nicaean army was led by representatives of families established in Thrace since the eleventh century, Nikephoros Tarchaneiotes ${ }^{38}$ and John Petraliphas ${ }^{39}$ respectively. The second case has to do with the military campaigns of 1241 and 1246 that led to the submission of Thessalonike to John III. ${ }^{40}$ The chief architect of this success was the megas domestikos Andronikos Palaiologos. Akropolites clearly states that Andronikos advised the emperor to conduct a European offensive while other dignitaries were against the proposal. ${ }^{41}$ Now since the twelfth century the Palaiologoi had been associated with the administration of Macedonia, and in particular of Thessalonike, its capital. An earlier Andronikos Palaiologos was dozx of the city in $c .1112,{ }^{42}$ while another had been among the city's defenders against the Normans in $1185 .{ }^{43}$ In 1246 Andronikos Palaiologos was the first govemor of Thessalonike under John III. His son, the future Michael VIII, was assigned the command of Melnik, Serres and the surrounding region, according to Akropolites. ${ }^{44}$ To put it simply, John III entrusted Macedonia to the Palaiologoi. In the Macedonian campaigns of the 1240 s we also find Nikephoros Tarchaneiotes and John Petraliphas, who had also been present in Thrace in the $1230 \mathrm{~s}$. They were accompanied by the mesazon Demetrios Tornikes

32 Georgii Acropolitae Opera, ed. Heisenberg, vol. 1, p. 124.

33 Theodori Ducae Lascaris Epistulae, ed. N. Festa (Florence, 1898), pp. 37, 97, 98 and 267.

34 Cheynet, Pouvoir et contestations, pp. 241-2.

35 Theodori Ducae Lascaris Epistulae, ed. Festa, p. 222.

36 Ibid., pp. 24, 165 and 172-6.

37 Ibid., pp. 162-5.

8 Georgii Acropolitae Opera, ed. Heisenberg, vol. 1, pp. 55-6.

39 Ibid., vol. 1, p. 58.

Ibid., vol. 1, p. 66.

Ibid., vol. 1, pp. 73-4.

2 Vannier, 'Les premiers Paléologues', p. 147.

43 Ibid., p. 164.

44 Georgii Acropolitae Opera, ed. Heisenberg, vol. 1, pp. 83-4. 
and the protobestiarios Alexios Raoul, both members of families established in Thrace from the eleventh and twelfth century respectively. ${ }^{45}$

From now on the decisive role of this European aristocracy posed a political threat to the Nicaean regime. Between 1246 and 1253 Michael Palaiologos, the future emperor, proceeded to multiply his intrigues on western soil. There are two contradictory testimonies about the scope of his actions: that of Akropolites, a chronicler loyal to the Palaiologan dynasty, and that of the more critical Pachymeres. Akropolites notes a project of marriage between Michael Palaiologos and the daughter of the Bulgarian tsar Kaliman I. ${ }^{46} \mathrm{It}$ is in fact possible that in this way the Palaiologoi attempted to redress the balance following the marriage between the porphyrogennetos Theodore and the daughter of JohnAsen $I I{ }^{47}$ But such a Bulgarian alliance would have tumed Michael Palaiologos into an emperor before his time, which is exactly Akropolites' point. The chronicler is probably trying to conceal a more scandalous intention, revealed by Pachymeres whose account appears more reliable. ${ }^{43}$ This historian mentions a secret pact concluded with Michael Angelos of Epiros, according to which the despotes would give his danghter in marriage to Palaiologos, who would surrender the western territories ruled by John III to Michael Angelos and would share power with him. ${ }^{49}$ In any case Michael Palaiologos was incarcerated in autumn 1253 for about a year. ${ }^{50} \mathrm{He}$ was only set free in order to be transferred to the administration of Bithynia, far away from suspect territory and under the control of the Laskarids.

The first year of the reign of Theodore II in 1255 witnessed a vast conspiracy orchestrated by the European aristocracy. ${ }^{51}$ Two officials were blinded on imperial orders, Theodore Philes, governor of Thessalonike, and Constantine, son of the governor of Serres; Alexios Strategopoulos was removed from office. Other aristocrats had their titles revoked. In the case of Nikephoros Alyates, epi tou kanikleiou, he also had his tongue cut out. Next the protobestiarios Alexios Raoul (whose sons were imprisoned), the megas primmikerios Constantine Tornikes and the parakoimomenos George Zagarommates lost their titles. All four maintained close links with the European provinces. The Alyates clan is well attested in the

45 Cheynet, Pouvoir et contestations, pp. 220 and 241

46 Georgii Acropolitae Opera, ed. Heisenberg, vol. 1, pp. 93-5.

47 Günter Prinzing, 'Eìn Mann tyrannidos axios. Zur Darstellung der rebellischen Vergangenheit Michaels VIII Palaiologos', in Ioannis Vassis, Günther S. Heinrich and Diether R. Reinsch (eds), Lesarten. Festschrift für Athanasios Kambylis zum 70. Geburtstag (Berlin, 1998), pp. 180-97.

48 See translator's Introduction in George Akropolites, The History, transl. Macrides, p. 73 . 1, p. 37 .

Georges Pachymérès, Relations historiques, ed. Failler and transl. Laurent, vol.

50 Albert Failler, 'Chronologie et composition dans l' Histoire de Georges Pachymère', Revue des études byzantines, 38 (1980): pp. 5-103, here pp. 10-16.

51 Georgii Acropolitae Opera, ed. Heisenberg, vol. 1, pp. 154-5. 
West in the early thirteenth century: an Alyates was protobestiarios of Emperor Theodore Doukas Komnenos Angelos in $1228 . .^{52}$ Alexios Raoul had been appointed governor of the reconquered territories of Epiros by John $\mathrm{MI} .{ }^{53}$ Constantine Tornikes was a military commander at Serres in Macedonia. ${ }^{54}$ George Zagarommates was the husband of Irene Maliasene, herself a member of a powerful family from Thessaly. 55

At this time of extreme tension between the European aristocracy and Theodore II one may wonder, where were the Palaiologoi? According to Pachymeres, the future emperor was warned by someone from within the imperial palace that he risked being blinded; he was thus forced to flee to the Seljuks in the summer of 1256. ${ }^{56}$ His uncle and namesake, the megas chartoularios Michael Palaiologos, was imprisoned, and his brother John Palaiologos was banished to the island of Rhodes. ${ }^{57}$ There is therefore no doubt that the entire Palaiologos family was in conflict with Theodore II precisely at the moment of the clash between emperor and western aristocracy. Yet in 1257 the future Michael VIII was set free and appointed governor of Dyrrachion. ${ }^{58}$ However, in the same year, during a visit to Thessalonike, he was arrested again for treason..$^{59}$ The repeated occurrence of such episodes demonstrates clearly that a deep gap divided the ruling dynasty from a faction led by the Palaiologoi.

For his part, the emperor Theodore II attempted by all means to secure his power in the East, in particular in the Bithynian cradle of the dynasty. Although his patronymic was Batatzes, this name is absent from one of his own writings, the encomium to his father. In this way Theodore II attached himself to the Nicaean roots of the regime. Tryphon, the patron saint of Nicaea, was promoted to protector

52 Nikos Bees and Helene Bees-Seferlis, 'Unedierte Schriftstücke aus der Kanzlei des Johannes Apokaukos des metropoliten von Naupaktos (in Aetolien)', Byzantinischnetugriechische Jahrbücher, 21 (1976): pp. 57-243, here p. 78.

53 Georgii Acropolitae Opera, ed. Heisenberg, vol. 1, p. 92.

54 Ibid., vol. 1, p. 114.

35 Marina Loukaki, 'Ein unbekanntes Gebet von Georgios Zagarommates an Johannes Prodromos', Jahrbuch der österreichischen Byzantinistik, 46 (1996): pp. 243-9. I thank Paul Magdalino for this reference.

56 Georges Pachymérès, Relations historiques, ed. Failler and transl. Laurent, vol. 1, pp. 43-5.

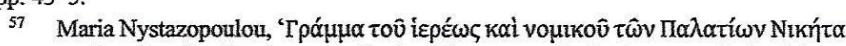

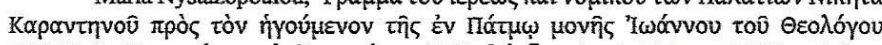

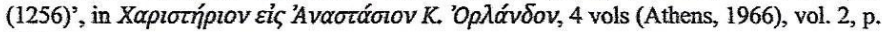
305.

58 Georges Pachymérès, Relations historiques, ed. Failler and transl. Laurent, vol. 1, pp. $45-7$.

59 Ibid., vol. 1, pp. 47-57. 
of the empire and was represented on its coinage. ${ }^{60}$ According to the chronicler Skoutariotes the saint had appeared in a dream to the emperor during his European campaign of $1255 .^{61}$ More importantly, though, Theodore II relied systematically on the aristocracy of north-western Asia Minor, reinforcing the ties formed during his father's reign. Apart from the case of the Mouzalones, one must realize that the imperial entourage was recruited from among the aristocracy. It is true that many of these individuals did not enter the nexus of clans related to the imperial family until the reign of Theodore II. But the same claim can be made for the party of the Palaiologoi, which was not really promoted until the reign of Michael VIII. Theodore II chose for the patriarchate Arsenios Autoreianos, who possessed two important advantages for the emperor: his family ties and his membership of the Bithynian clergy. On the family front, he hailed from the Autoreianoi and the Kamateroi, on whom Theodore I Laskaris had relied heavily. From the ecclesiastical point of view he maintained close links with the patriarchate of Nicaea and more generally with Bithynia. Under John III an Autoreianos had been deacon of the patriarchate, ${ }^{62}$ showing that the family was permanently linked with the ecclesiastical administration in the wake of Michael IV Autoreianos' patriarchate. Moreover, Arsenios spent time in four monasteries of Bithynia or its wider region: Oxeia on the Princes' Islands, Pitharitzia (whose hegoumenos he had been), St Anne at Oxybapheion, and St George at Apollonia. ${ }^{63}$

Among the secular aristocracy the Mouzalon brothers were promoted at court in a spectacular fashion, receiving prestigious wives: in particular the chief minister George Mouzalon, who accumulated the titles of protosebastos, protobestiarios and megas stratopedarches, and married a daughter of John Kantakouzenos and Irene Palaiologina. ${ }^{64}$ One may also note the case of the Nestongos clan: the three brothers George, Theodore and Isaac were the chief generals of Theodore II. ${ }^{65}$ The doux of Thrakesion George Makrenos falls into the same category. ${ }^{66}$ It is worth remembering that the Nestongoi and Makrenoi, following the Laskarids, conspired in the early days of the reign of John III. One may therefore conclude that Theodore II relied on the same aristocratic group as the founder of the empire of Nicaea.

The creation of two parties behind the Palaiologoi and the Laskarids respectively thus illuminates the political developments of the year 1258. As we know, George Mouzalon, the regent of the empire appointed by Theodore II before his death, was

60 Michael Hendy, Coinage and Money in the Byzantine Empire, 1081-1261 (Washington, DC, 1969), pp. 256-61.

61 Georgii Acropolitae Opera, ed. Heisenberg, vol. 1, p. 291.

62 Nicephori Blemmydae Autobiographia, ed. Munitiz, p. 55.

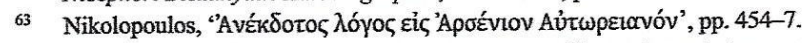

64 Georges Pachymérès, Relations historiques, ed. Failler and transl. Laurent, vol. 1, p. 41.

65 Georgii Acropolitae Opera, ed. Heisenberg, vol. 1, pp. 115, 142 and 151.

66 Miklosich and Maller (eds), Acta et diplomata, vol. 4, pp. 211 and 247. 
assassinated in that year. The murder was carried out at the instigation of victims of the Laskarid regime. Pachymeres describes the divisions among the aristocracy at the time of the appointment of a new regent in great detail. ${ }^{67}$ On one side the ambitions of Michael and Manuel, two elderly brothers of Theodore I Laskaris, and of George Nestongos were made manifest. On the other, there were the Tornikioi, the Strategopouloi and Michael Palaiologos. The aristocracy was thus faced with two options. The choice was inextricably linked to the military situation. In view of the threat posed to the western provinces in 1258 by the powerful coalition of the Greek ruler of Epiros, the Frankish prince of Achaia and the king of Sicily, it appeared that the time of the European aristocracy had finally come. Michael Palaiologos took upon himself the role of defender of Thessalonike, claiming that the city was his home and that his father lay buried there: ${ }^{68}$ both claims were fabrications, for he had been bom in Nicaea where the last tomb of Andronikos Palaiologos was also to be found. ${ }^{69}$ What is more, he invoked the protection of St Demetrios, allegedly the ancestral patron of the Palaiologoi ${ }^{70}$ - an obvious link with the Macedonian capital city. Thus the rise of the future Michael VIII may be explained essentially by the support he received from an aristocracy primarily attached to the defence of the European provinces.

To conclude, the question of the identity and allegiances at work in the empire of Nicaea demonstrates the value of a prosopographical approach. The study of the supporters and opponents of the emperors cannot be carried out without prior knowledge of their careers, their family links and their local power base. Such an approach to the study of the Byzantine aristocracy reveals the significance of investigations covering a longer time-span and the necessity to look at the pre1204 period in order to understand the thirteenth century. In this respect, the value of Prosopography of the Byzantine World's timeframe from 1180 to 1261 fits well with this renewal of political history. The Byzantine aristocracy is characterized by considerable continuity among those clans that held power, even if new clans readjusted their family ties. On the other hand several cracks within the ruling elites date back to the late Komnenian age and to the period of the Angeloi. The most important is undoubtedly the division between two aristocratic groups focused on the defence of either the East or the West. Paradoxically the empire of Nicaea

${ }^{67}$ Georges Pachymérès, Relations historiques, ed. Failler and transl. Laurent, vol 1,pp. 91-115.

68 Georgii Acropolitae Opera, ed. Heisenberg, vol. 1, p. 158.

69 See Jacob of Ohrid (Bulgaria): Iacobi Bulgariae archiepiscopi Opuscula, ed. S.G. Mercati, Bessarione, 21 (1917), pp. 73-89 and 208-27, reprinted in Silvio Giuseppe Mercati, Collectanea Byzantina, 2 vols (Bari, 1970), vol. 1, pp. 66-98, here pp. 72, 79-80 and 112. However, it is true that Andronikos Palaiologos' first tomb was to be found in Thessalonike.

70 Typikon of the monastery St Demetrios of the Palaiologoi in Constantinople, in Henri Grégoire, 'Imperatoris Michaelis Palaeologi de vita sua', Byzantion, 29-30 (195960): pp. 447-74. 
witnessed the triumph of the European aristocracy led by the Palaiologoi. This is a fact of cardinal significance that helps to explain the ultimate fate of Byzantium. 


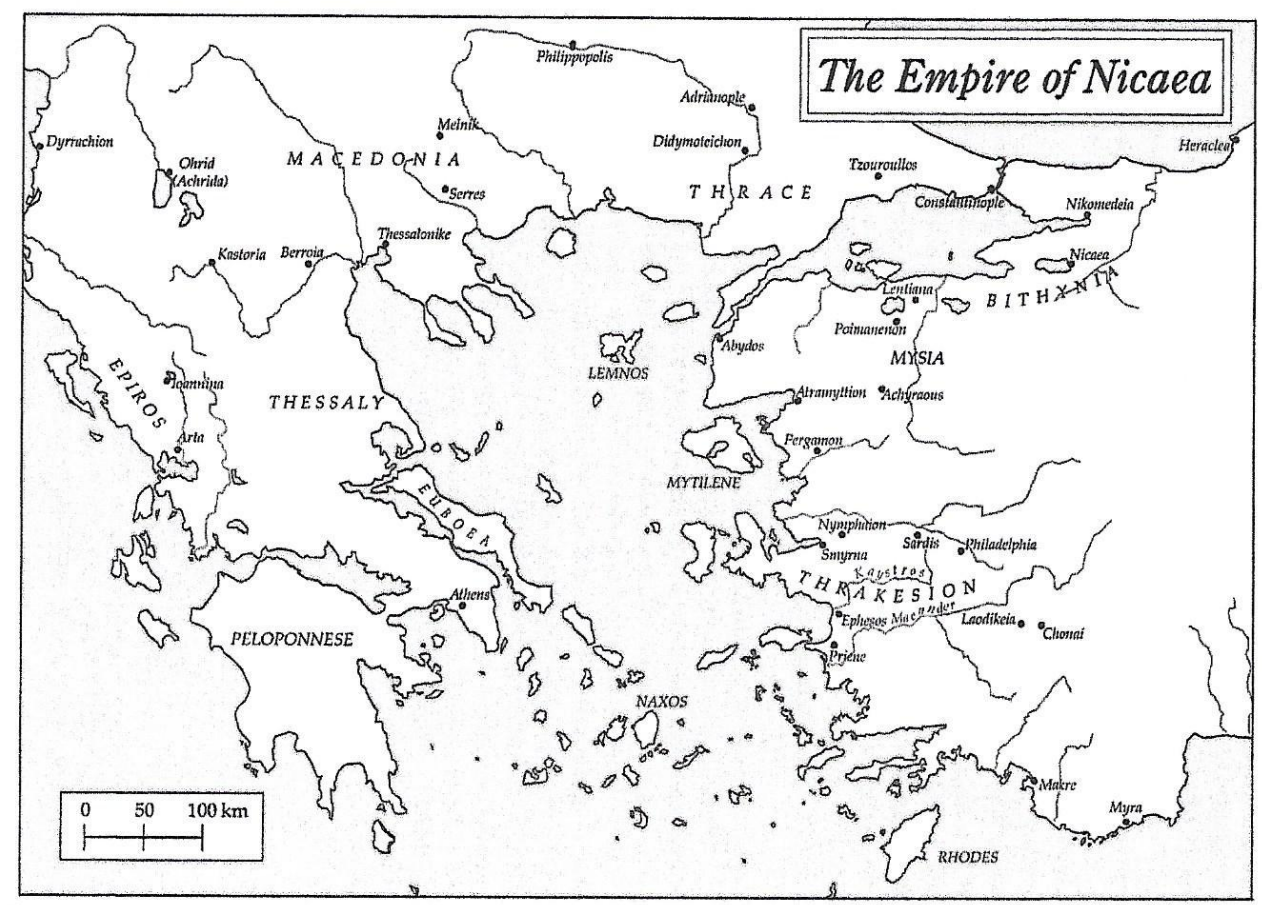

